\title{
Potensi Kandungan Karbon Keragaman Spesies Lamun di Perairan Pesisir Selatan Lombok Timur
}

\author{
Potential Carbon Content of Seagrass Species Diversity \\ in South Coastal Waters of East Lombok
}

\author{
I Gusti Ayu Sintia Dewi*, Abdul Syukur, I Gde Mertha \\ Pendidikan Biologi,Fakultas Keguruan dan Ilmu Pendidikan, Universitas Mataram, \\ Mataram, Indonesia \\ *Corresponding Author Email : ayusintia427@gmail.com
}

Manuscript received: 08-07-2021. Accepted: 27-10-2021

\begin{abstract}
ABSTRAK
Lamun dapat memainkan peranan penting dalam mengurangi pemanasan global dan mitigasi perubahan iklim melalui pengembangan karbon zink sebagai bahan organic yang dihasilkan dari proses fotosintesis dan disimpan dan dialirkan dalam bentuk biomassa vegetasi lamun. Lamun salah satu vegetasi perairan yang mampu menyerap dan menyimpan karbon. Lamun memiliki kemampuan untuk menyerap karbon melalui proses fotosintesis. Tujuan penelitian ini untuk menggambarkan kandungan karbon potensial dari spesies lamun di Perairan Pesisir Selatan Lombok Timur. Jenis penelitian ini adalah penelitian yang bersifat diskriptif ekspolaratif. Metode penelitian adalah metode transek kuadrat. Populasi penelitian ini adalah semua spesies lamun yang terdapat dalam 3 stasiun penelitian. Data yang telah di koleksi selanjutnya di lakukan analisis data menggunakan analisis komposisi jenis lamun, tutupan lamun, kerapatan lamun, keanekaragaman, keseragaman, dominansi dan analisis kadar karbon melalui biomassa tegakan lamun (daun, rhizome/batang dan akar). Hasi penelitian ini adalah ditemukannya 9 Spesies lamun di Pantai Lungkak dan 5 spesies lamun di Gili Kere dan Poton Bakau. Kerapatan spesies di tiga lokasi penelitian berkidsar anatara 0,0956,91 tegakan $/ \mathrm{m} 2$. Nilai biomassa lamun berkisar antara 1,47-261,9 gbk/m2 dan total kandungan karbon berkisar antara 295,91 $\pm 202,88 \mathrm{gC}$. Nilai biomassa dan kandungan karbon ini didominansi oleh spesies lamun yang memiliki morfologi besar seperti Enhalus acroides, Thalasia hemprici, Cymodocea rotundata, dan Cymodocea serullata dan nilai kerapatan serta tutupan lamun yang tinggi. Hubungan antara tutupan lamun dengan karbon lamun memiliki hubungan yang signifikan dimana semakin tinggi tutupan lamun maka nilai kandungan karbon lamun juga akan semakin meningkat.
\end{abstract}

Kata kunci : lamun; biomassa; kandungan karbon

\footnotetext{
ABSTRACT

Seagrass can play an important role in reducing global warming and mitigating climate change through the development of carbon zinc as an organic material produced from photosynthesis and stored and transported in the form of seagrass vegetation biomass. Seagrass is one of the aquatic
} 
vegetation that is able to absorb and store carbon. Seagrasses have the ability to absorb carbon through the process of photosynthesis. The purpose of this study was to describe the potential carbon content of seagrass species in the South Coastal Waters of East Lombok. This type of research is an expolarative descriptive research. The research method is a quadratic transect method. The population of this study were all seagrass species contained in 3 research stations. The collected data was then analyzed using analysis of seagrass species composition, seagrass cover, seagrass density, diversity, uniformity, dominance and analysis of carbon content through seagrass stand biomass (leaves, rhizomes/stems and roots). The result of this research is the discovery of 9 species of seagrass on Lungkak Beach and 5 species of seagrass on Gili Kere and Poton Bakau. The species density in the three study sites ranged from 0.09 to 56.91 stands $/ \mathrm{m} 2$. Seagrass biomass values ranged from 1.47$261.9 \mathrm{gbk} / \mathrm{m} 2$ and total carbon content ranged from $295.91 \pm 202.88 \mathrm{gC}$. The value of this biomass and carbon content was dominated by seagrass species with large morphology such as Enhalus acroides, Thalasia hemprici, Cymodocea rotundata, and Cymodocea cerillata and high density and cover values of seagrass. The relationship between seagrass cover and seagrass carbon has a significant relationship where the higher the seagrass cover, the higher the carbon content of the seagrass.

Keywords : seagrass; biomass; carbon content

\section{PENDAHULUAN}

Lamun adalah tumbuhan monokotil yang mempunyai akar, rimpang (rhizoma), daun, bunga dan buah (Tangke, 2010). Lamun memiliki fungsi secara fisik sebagai stabilisator perairan dengan sistem perakannya yang dapat menangkap sedimen, mengubah hidrodinamika dan memodifikasi proses biogeokimia dalam kolom air dan sedimen (Belshe et al., 2018, Rahman et al., 2016). Lamun salah satu vegetasi perairan yang mampu menyerap dan menyimpan karbon (Huang et al., 2015; Marba et al., 2015; Lymo, 2016). Peningkatan karbon yang sangat pesat di atmosfer menjadi pemicu terjadinya pemanasan global (Rahmah et al., 2015; Windarni et al., 2019; Rahman et al., 2017). Meskipun demikian pemanasan global dan perubahan iklim dapat dikurangi melalui pengembangan karbon zink sebagai bahan organic yang dihasilkan dari proses fotosintesis dan disimpan dan dialirkan dalam bentuk biomassa vegetasi lamun (Marjan et al., 2016; Chanan, 2014).

Lamun memiliki kemampuan untuk menyerap karbon melalui proses fotosintesis. Lamun mampu menyerap karbon dengan rata-rata 0,21 ton/ha (Graha, 2016). Berdasarkan penelitian Supriadi (2014) lamun mampu menyerap karbon sebesar 1.15 ton/ha, dengan kandungan di bawah substrat sebesar 0.88ton/ha (76,3\%), lebih tinggi dibanding karbon di atas substrat yang hanya 0,27 ton/ha $(23,7 \%)$. Jumlah penyimpanan karbon pada vegetasi lamun yang tinggi menunjukkan ekosistem lamun dapat memainkan peranan yang penting dalam mitigasi perubahan iklim (Wawo et al., 2014).

Pulau Lombok adalah salah satu wilayah di Indonesia yang memiliki ekosistem lamun dengan kondisi yang baik dan masih terjaga (Ramdhoni, 2017). Salah satunya ekositem lamun di pesisir Lombok Timur. Studi tentang hal ini menunjukkan bahwa pada areal seluas 56.65 ha pada padang lamun di Poton Bakau Lombok Timur adalah 249.27 ton C/ha (Rahman et al., 2018). Namun demikian, penelitian tentang potensi kandungan karbon masih terbatas. Sementara itu, kandungan karbon pada setiap spesies lamun sangat penting sebagai instrument konservasi atau pengelolaan lamun untuk keberlanjutan ekologi dan ekonomi masyarakat lokal dan pengurangan dampak akibat pemanasan global. Oleh karena 
itu, perlu dilakukan penelitian tentang Potensi Kandungan Karbon Keragaman Spesies Lamun di Perairan Pesisir Selatan Lombok Timur.

\section{BAHAN DAN METODE}

\section{Lokasi dan waktu penelitian}

Penelitian dilaksanakan pada bulan Januari 2021 di Perairan Pantai Lombok Timur, khusunya Poton Bako, Lungkak, dan Gili Kere. Penelitian ini bersifat deskriptif yang berorientasi eksploratif. Penelitian ini mendeskripsikan tentang Potensi Kandungan Karbon Keragaman Lamun di Perairan Pesisir Selatan Lombok Timur, kemudian dilakukan eksplorasi tentang hubungan faktor-faktor lingkungan. Populasi dalam penelitian adalah semua spesies lamun yang terdapat di 3 stasiun penelitian yaitu Lungkak, Poton Bakau dan Gili Kere.

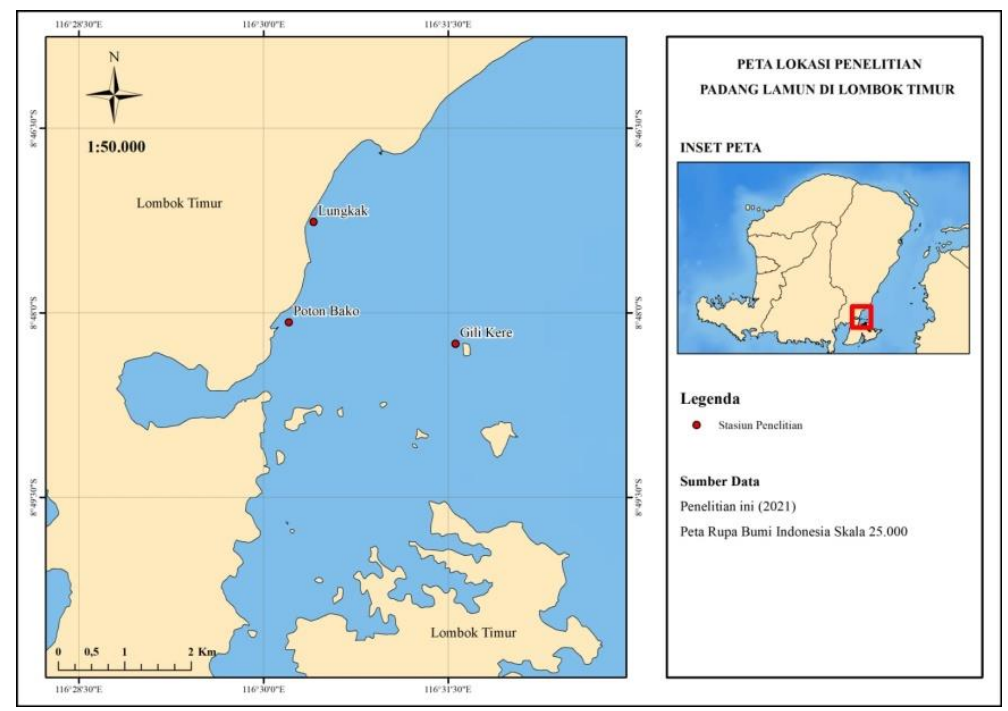

Gambar 1. Lokasi penelitian

\section{Alat dan bahan}

Alat dan bahan penelitian yang digunakan yakni GPS receiver, thermometer, refraktometer, kamera, kuadran ukuran 1x1 meter, ph meter, buku penuntun identifikasi lamun, roll meter ukuran 100 meter, thermometer air raksa, do meter, neraca analitik, oven, alumunium foil dan kertas buram, cawan porselen, bunsen, plastik es batu.

\section{Pengambilan data}

Pengambilan data lamun mengacu pada buku identifikasi lamun seagrasswatch dengan menggunakan metode transek kuadrat (tegak lurus garis pantai). Variabel yang teramati adalah jenis spesies lamun, tutupan lamun, dan jumlah tegakan lamun. Kemudian dari data yang diperoleh dilakukan analisis kerapatan lamun dan persentase penutupan lamun, dominasi, biomassa dan kandungan karbon. Pengamatan lamun dilakukan dengan cara menempatkan transek kuadrat dengan ukuran 1m x 1m (Kenzie et al., 2003).

Pengambilan sampel lamun dilakukan dengan mencuplik lamun sampai pada kedalaman penetrasi akar dengan pemotongan rhizome yang menjalar kesamping (batas luar kuadran/transek). Sampel lamun yang berupa herbarium basah, dipisahkan menurut organnya 
yaitu akar, rhizome dan daun, kemudian dipotong-potong menjadi bagian terkecil dan ditimbang berat basahnya (Graha et al., 2016). Sampel lamun basah kemudian dimasukkan kedalam oven dengan temperature $60{ }^{\circ} \mathrm{C}-70{ }^{\circ} \mathrm{C}$ hingga kering kemudain ditimbang kembali untuk berat kering. Sampel lamun yang diukur berat basah dan berat keringnya, maka didapatkan nilai biomassa pada setiap organnya (Duarte, 1990).

Perhitungan kandungan karbon sampel jaringan lamun (daun, rhizome, akar) dianalisis menggunakan metode pengabuan atau Loss On Ignition (Helrich, 1990) yang di lakukan di Laboratorium Biologi FKIP Universitas Mataram. Perhitungan kandungan karbon hanya dilakukan pada meter ke- 50 kemudian dikonversi dengan nilai biomassa disetiap titik 0 dan 100 dalam satu garis transek. Hasil konversi karbon keseluruhan kemudian dirata-rata dengan satuan $\mathrm{g} \mathrm{C} / \mathrm{m}^{2}$ dan dikalikan dengan luas lamun disuatu lokasi (Howards et al., 2014).

\section{Analisis data}

Komposisi lamun dihitung berdasarkan rumus (Brower, et al., 1990):

$$
\mathrm{P}=\frac{N i}{N} \times 100 \%
$$

Keterangan :

$\mathrm{P}=$ Persentase setiap lamun $(\%)$

$\mathrm{Ni}=$ Jumlah setiap spesies $\mathrm{i}$

$\mathrm{N}$ = Jumlah total seluruh spesies

Kerapatan dihitung berdasarkan rumus (Khouw, 2009):

$$
\mathrm{K}=\mathrm{ni} / \mathrm{A}
$$

Keterangan:

$\mathrm{K}=$ Kepadatan spesies ke-i (ind. $\mathrm{m}^{-2}$ )

$\mathrm{ni}=$ Jumlah seluruh individu (ind)

$\mathrm{A}=$ Luas area sampling $\left(\mathrm{m}^{2}\right)$

Indeks keanekaragaman dihitung dengan menggunakan rumus Shannon-Wiener (Fachrul, 2007):

$$
\mathrm{H}^{\prime}=-\sum_{i=1}^{s} P i \ln P i
$$

Keterangan:

$\mathrm{H}^{\prime}=$ Indeks keanekaragaman

$\mathrm{Pi}=\mathrm{ni} / \mathrm{N}$

$\mathrm{ni}=$ jumlah individu spesies ke-I

$\mathrm{N}=$ total jumlah individu 
Indeks keseragaman dihitung dengan menggunakan rumus menurut Krebs (1994):

$$
\mathrm{E}=\frac{H^{\prime}}{\log 2 S}=\frac{H^{\prime}}{H \operatorname{makS}}
$$

Keterangan:

$\mathrm{E}=$ Indeks keseragaman

$\mathrm{H}^{\prime}=$ Indeks keanekaragaman

$\mathrm{S}=$ Jumlah spesies

Indeks dominansi dihitung dengan menggunakan rumus dominansi (D) Simpson (Krebs, 1994):

$$
\mathrm{D}=\sum(\mathrm{ni} / \mathrm{N})^{2}
$$

Keterangan:

$\mathrm{D}=$ Indeks dominansi

$\mathrm{ni}=$ Jumlah individu spesies ke-i

$\mathrm{N}=$ Jumlah total seluruh individu

Rumus yang digunakan untuk menghitung biomassa ditunjukkan oleh persamaan menurut Duarte (1990):

$$
\mathrm{B}=\mathrm{W} \times \mathrm{D}
$$

Keterangan:

B = Biomassa Lamun (gram.m- 2)

$\mathrm{W}=$ Berat Kering sebuah tunas lamun (gram.tunas-1)

$\mathrm{D}=$ Kepadatan Lamun (tunas.m- 2)

Rumus yang digunakan untuk menghitung kandungan karbon jaringan lamun dengan metode pengabuan dapat dihitung dengan persamaan oleh Helrich (1990):

$$
\text { Kadar } \mathrm{Abu}=\frac{\mathrm{c}-\mathrm{a}}{\mathrm{b}-\mathrm{a}} \mathrm{x} 100 \%
$$

Keterangan:

$\mathrm{a}=$ berat cawan

$\mathrm{b}=$ berat cawan + berat kering jaringan lamun

$\mathrm{c}=$ berat cawan + berat abu jaringan lamun

Bahan organik dihitung dengan metode pengabuan yaitu pengurangan berat saat pengabuan oleh Helrich (1990):

$$
\text { Kadar bahan organic }=\frac{[(b-a)-(c-a)]}{(b-a)} \times 100 \%
$$

Keterangan:

$\mathrm{a}=$ berat cawan

$\mathrm{b}=$ berat cawan + berat sampel

$\mathrm{c}=$ berat (cawan $+\mathrm{abu})$ 
Nilai kandungan karbon jaringan lamun dihitung dengan persamaan (Helrich, 1990):

$$
\text { Kandungan karbon }=\frac{\text { Kadar bahan organik }}{1,724} \times 100 \%
$$

Keterangan:

$1,724=$ Nilai konstan

Nilai hasil kandungan karbon tersebut kemudian dirata-rata sebagai nilai kandungan karbon jaringan lamun (Graha, 2015).

Total stok karbon lamun dihitung dengan menggunakan rumus menurut Sulaeman et al. (2005):

$$
\mathrm{Ct}=\Sigma(\mathrm{Li} \times \mathrm{ci})
$$

Keterangan :

$\mathrm{Ct}=$ karbon total (ton)

$\mathrm{Li}=$ luas padang lamun kategori kelas $\mathrm{i}(\mathrm{m} 2)$

$\mathrm{Ci}=$ rata-rata stok karbon lamun kategori kelas i $(\mathrm{gC} / \mathrm{m} 2)$

Hubungan antara kerapatan lamun dengan karbon lamun dianalisis dengan analisis regresi linear sederhana. Berikut persamaan regresi linear sederhana yaitu sebagai berikut:

$$
Y=a+b X
$$

Dimana:

$\mathrm{Y}=$ variabel response atau variabel akibat (dependent)

$\mathrm{X}=$ Variabel predictor atau Faktor penyebab

(independent)

$\mathrm{a}=$ Konstanta

$\mathrm{b}=$ Koefisien regresi

\section{HASIL DAN PEMBAHASAN}

Komposisi, kerapatan, dan tutupan lamun

Kawasan pesisir selatan Lombok Timur merupakan kawasan yang memiliki luas lamun yang berpotensi menjadi kawasan karbon biru Indonesia. Berdasarkan pengamatan di tiga lokasi pengamatan di Pantai Lungkak, lamun yang ditemukan terdiri dari 9 jenis lamun dari yang digolongkan menjadi 2 famili yaitu Potamogetonaceae dengan 5 spesies yaitu Halodule pinifolia, Halodule uninervis, Cymodocea serulata, Syringodium isoetifolium dan Cymodocea rotundata dan family Hydrocharitaceae yang terdidri dari 4 spesies yaitu Halopila ovalis, Halopila decipiens, Enhalus acroides, dan Thalasia hemprichi. Sedangkan lamun yang ditemukan di Gili Kere dan Poton Bako terdiri dari 5 jenis lamun yang digolongkan menjadi 2 famili yaitu Potamogetonaceae dengan spesies 2 yaitu Halodule pinifolia dan Cymodocea rotundata dan family Hydrocharitaceae yang terdidri dari 3 spesies 
yaitu Halopila ovalis, Enhalus acroides, dan Thalasia hemprichi. Komposisi lamun di Pantai lungkak memilki komposisi yang sama dengan lamun yang ditemukan di di Tanjung Luar Lombok Timur (Syukur et al. 2017), namun berbeda dengan komposisi lamun yang ditemukan di Gili Kere dan Poton Bako yang memiliki komposisi lebih rendah dibandingankan komposisi lamun yang di temukan di Tanjung Luar Lombok Timur (Syukur et al. 2017). Adanya perbedaan komposisi jenis pada tiap lokasi penelitian disebabkan oleh kurangnya kemampuan untuk berkompetisi dengan jenis lamun yang mempunyai bentuk morfologi daun besar seperti Enhalus acroides, hal ini terlihat spesies Thalasia hemprchi, cymodecoea rotundata, dan Halopila ovalis yang ditemukan pada lokasi pengamatan mempunyai ukuran morfologi daun yang kecil tidak seperti umumnya. Pertumbuhan lamun diduga dapat dipengaruhi oleh factor internal seperti kondisi fisiologi dan metabolism, serta factor eksternal seperti zat hara dan tingkat kesuburan perairan (Hartati et al, 2012). Komposisi lamun dapat dilihat pada tabel 1.

.Tabel 1. Komposisi lamun(\%)

\begin{tabular}{lccc}
\hline \multirow{2}{*}{ Spesies lamun } & \multicolumn{3}{c}{ Lokasi } \\
\cline { 2 - 4 } & Lungkak & Gili Kere & Poton Bakau \\
\hline Halodule pinifolia & 31.81 & 25.94 & 4.46 \\
Cymodocea rotundata & 19.09 & 41.91 & 0.13 \\
Enhalus acroides & 5.48 & 13.17 & 61.60 \\
Halophila ovalis & 7.01 & 3.33 & 26.54 \\
Thalasia hemprichi & 7.11 & 15.66 & 7.26 \\
Cymodocea serulata & 12.72 & 0.00 & 0.00 \\
Syringodium isoetifolium & 11.05 & 0.00 & 0.00 \\
Halodule uninervis & 3.12 & 0.00 & 0.00 \\
Halophila decipiens & 2.60 & 0.00 & 0.00 \\
\hline Total & 100.00 & 100.00 & 100.00 \\
\hline
\end{tabular}

Komposisi dan struktur lamun berkaitan dengan nilai kerapatan, sebaran, dan persentase tutupan lamun pada setiap jenis lamun. Nilai kerapatan lamun dapat dilihat pada tabel 2.

Tabel 2. Kerapatan lamun (tegakan/m²)

\begin{tabular}{lccc}
\hline \multirow{2}{*}{ Spesies lamun } & Lungkak & Gili Kere & $\begin{array}{l}\text { Poton } \\
\text { Bakau }\end{array}$ \\
\cline { 2 - 4 } & 56,91 & 32,62 & 3,04 \\
Halodule pinifolia & 31,85 & 50,18 & 0,09 \\
Cymodocea rotundata & 12,25 & 16,56 & 41,95 \\
Enhalus acroides & 11,40 & 4,18 & 18,07 \\
Halophila ovalis & 14,18 & 19,69 & 4,95 \\
Thalasia hemprichi & 19,69 & 0,00 & 0,00 \\
Cymodocea serulata & 15,95 & 0,00 & 0,00 \\
Syringodium & 5,85 & 0,00 & 0,00 \\
isoetifolium & 4,71 & 0,00 & 0,00 \\
Halodule uninervis & 172,79 & 123,23 & 68,10 \\
Halophila decipiens & & & \\
\hline Total & & &
\end{tabular}


Kerapatan tertinggi di Pantai Lungkak adalah Halodule pinifolia. Tingginya nilai komposisi dan kerapatan Halodule pinifolia yaitu 31,81\% (Tabel 1) dan 56,91\% (Tabel 2) di Pantai Lungkak disebabkan substrat di lokasi penelitian adalah pasir halus dan berlumpur. Hal tersebut sesuai dengan pendapat Riniatsih (2007) bahwa lamun jenis ini umumnya dijumpai pada daerah intertidal dan biasanya tumbuh pada substrat berpasir atau berlumpur. Spesies ini tergolong jenis lamun yang pertumbuhannya cepat dan merupakan spesies pionir di yang dominan dalam perairan yang mengalami gangguan dan tidak stabil (Lisdawati, 2018). Selain itu, Nienhuis (1989) menyatakan bahwa variasi kerapatan jenis lamun pada suatu lokasi memiliki hubungan yang signifikan terhadap morfologi dari tiap jenis lamun. Semakin kecil morfologi daun lamun maka kemungkinan kerapatan lamun tersebut tinggi cukup besar.

Komposisi dan kerapatan spesies lamun yang tertinggi di Gili Kere adalah Cymodecea rotundata yaitu $41,91 \%$ dan 58,18 itegakan $/ \mathrm{m}^{2}$. Tingginya nilai komposisi dan kerapatan Cymodecea rotundata disebabkan oleh kondisi di lokasi penelitian merupakan perairan yang dangkal dan bahkan terekspose ketika surutnya air laut, sehingga jenis lamun ini lebih mudah untuk berkembang dibanding jenis lainnya (Hidayat et al, 2018). Menurut Brouns (1986), jenis lamun Cymodecea rotundata menyukai perairan yang terpapar sinar matahari, dimana jenis ini merupakan jenis lamun kosmopolit, yaitu dapat tumbuh hampir di semua kategori habitat. Hal ini setara dengan pendapat (Yunita et al, 2020) yang menyatakan bahwa spesies lamun ini dapat beradaptasi terhadap berbagai macam kondisi lingkungan.

Tingginya nilai komposisi dan kerapatan spesies Enhalus acroides di Pantai Poton Bako yaitu 61,60\% (Tabel 2) dan 41,95 tegakan $/ \mathrm{m}^{2}$, disebabkan oleh spesies ini umumnya ditemukan tumbuh pada substrat berlumpur di perairan yang keruh, dapat membentuk spesies tunggal serta dapat mendominasi komunitas padang lamun (Short and Coles, 2001). Menurut Tomascik et al (1997) pada lingkungan perairan lebih didominasi substrat berlumpur, Enhalus acroides cenderung merupakan komunitas klimaks dimana kondisi lingkungan menjadi tidak sesuai untuk spesies lainnya. Selain itu, Enhalus acroides mempunyai kecepatan pertumbuhan yang cepat dibandingkan jenis lamun lainnya, hal inilah yang menyebabkan penyebaran spesies ini menjadi merata (Putri, 2004).

Persentase penutupan lamun berfungsi untuk menggambarkan luasan lamun yang menutupi perairan (substrat) dalam batasan kuadrat yang telah ditentukan dengan posisi pengamat tegak lurus kuadrat yang dinyatakan dalam satuan persen (\%) (Ganefiani et al., 2019). Berdasarkan pendapat Kasim (2013) yang menyatakan bahwa persentase penutupan lamun tidak selamanya linear dengan tingginya kerapatan jenis. Hal ini dipengaruhi pengamatan penutupan yang diamati adalah helaian daun, sedangkan kerapatan yang dilihat adalah jumlah tegakan lamun. Makin lebar ukuran panjang dan lebar daun lamun maka akan semkain besar menutupi substart dasar perairan. Persentase penutupan lamun dapat dilihat pada tabel 3 . 
Tabel 3. Tutupan lamun (\%)

\begin{tabular}{lccc}
\hline \multirow{2}{*}{ Spesies lamun } & \multicolumn{3}{c}{ Lokasi } \\
\cline { 2 - 4 } & Lungkak & Gili Kere & $\begin{array}{c}\text { Poton } \\
\text { Bakau }\end{array}$ \\
\hline Halodule pinifolia & 10,91 & 5,97 & 0,27 \\
Cymodocea rotundata & 13,18 & 24,00 & 0,09 \\
Enhalus acroides & 11,91 & 18,09 & 23,27 \\
Halophila ovalis & 4,36 & 1,18 & 7,54 \\
Thalasia hemprichi & 6,64 & 10,00 & 2,46 \\
Cymodocea serulata & 11,00 & 0,00 & 0,00 \\
Syringodium isoetifolium & 7,91 & 0,00 & 0,00 \\
Halodule uninervis & 1,36 & 0,00 & 0,00 \\
Halophila decipiens & 2,09 & 0,00 & 0,00 \\
\hline Total & 69.36 & 59.24 & 33.64 \\
\hline
\end{tabular}

Persentase penutupan lamun terendah terdapat di Pantai Poton Bakau yang hanya mencapai 33,64\% (Tabel 3), dikarenakan hanya ditemukan 5 jenis lamun dan dominan. Beberapa jenis lamun tidak terdapat di Pantai Poton Bakau)memepengaruhi rendahnya nilai penutupan lamun di lokasi ini. Persen penutupan lamun tertinggi terdapat di Pantai Lungkak sebesar 69,36\% (Tabel 3) Tingginya persen penutupan lamun di Pantai Lungkak dipengaruhi oleh ditemukannya banyak jenis lamun di Stasiun ini dan juga di pengaruhi oleh tingginya kerapatan jenis lamun yakni pada jenis lamun Halodule phinofolia dan Cymodocea rotundata. sedangkan tutupan lamun di Gili Kere adalah 59,24\% (Tabel3). Rata-rata tutupan lamun di Perairan Pesisir Selatan Lombok Timur adalah 54,08\% dan termasuk kategori padat (Hutomo \& Nontji, 2014).

\section{Indeks keanekaragaman, keseragaman, dan dominansi}

Indeks keanekaragaman menggambarkan kekayaan jenis lamun yang ada. Semakin tinggi nilai indeks keanekaragaman menunjukkan semakin tinggi keberagaman jenis lamun yang terdapat pada suatu perairan (Argadi, 2003). Tingkat keanekaragaman dihitung dengan menggunakan indeks keanekaragaman $\left(\mathrm{H}^{\prime}\right)$ Shanon-Wiener yang menunjukan bahwa keanekaragaman lamun di Perairan Selatan Lombok Timur tergolong kategori sedang (Magurran, 1988). Nilai keanekaragaman dari penelitian ini lebih tinggi jika dibandingkan rata-rata nilai keanekaragaman di Perairan Gili Asahan, Kabupaten Lombok Barat, yaitu 1,27 dengan nilai dominansi 0,34 (Rahman, et al., 2018). Keanekaragaman jenis suatu komunitas dapat dikatakan tinggi apabila komunitas tersebut tersusun dari banyak spesies dengan kelimpahan tiap spesies merata. Sebaliknya, keanekaragaman akan rendah apabila suatu komunitas tersusun atas sedikit spesies dan kelimpahan yang tidak merata (Handayani, 2006). Tinggi rendahnya nilai keanekaragaman dapat mempengaruhi keseragaman (E) dan dominansi (D) spesies lamun. Semakin kecil nilai keanekaragaman (H'), maka nilai keseragaman (E) akan semakin kecil. Hal tersebut mengisyaratkan bahwa adanya dominansi (D) suatu spesies didalam komunitas (Insafitri, 2010). Jika dominansi lebih terkonsentrasi pada satu spesies, nilai indeks dominansi akan meningkat dan sebaliknya jika berapa spesies mendominasi secara bersama-sama maka nilai indeks dominansi akan rendah (Katukdoan, et al., 2018). Nilai indeks keanekaragaman, keseragaman dan dominansi dapat dilihat pada tabel 4. 
Tabel 4. Indeks keanekaragaman, keseragaman dan dominansi

\begin{tabular}{cccc}
\hline \multirow{2}{*}{ Lokasi } & \multicolumn{3}{c}{ Indeks } \\
\cline { 2 - 4 } & H' & $\mathrm{C}$ & $\mathrm{E}$ \\
\hline Pantai Lungkak & 1,92 & 0,88 & 0,18 \\
Gili Kere & 1,45 & 0,90 & 0,44 \\
Pantai Poton Bakau & 0,99 & 0,61 & 0,46 \\
\hline
\end{tabular}

Indeks keanekaragaman ( $\left.\mathrm{H}^{\prime}\right)$ tertinggi terdapat di Pantai Lungkak dengan nilai 1,92 dan nilai keseragamannya 0,88 yang menandakan kelimpahan spesies merata dengan nilai dominansi rendah, yaitu 0.18. Tingginya keanekaragaman di Pantai Lungkak dikarenakan jumlah spesies lamun yang ditemukan di lokasi tersebut paling tinggi yaitu 9 spesies lamun. Selanjutnya nilai indeks keanekaragaman terendah terdapat di Pantai Poton Bakau dengan nilai 0,99. Rendahnya nilai keanekaragaman di lokasi ini sejalan dengan nilai dominansi yang lebih tinggi, yaitu 0,46. Hal yang menarik tejadi di Gili Kere dan Poton bakau. Jumlah spesies yang terdapat pada kedua lokasi ini sama, yaitu 5 spesies lamun tetapi nilai keanekaragaman di Poton Bakau $\left(H^{\prime}=0,99\right)$ tetap lebih rendah dibandingkan Gili Kere $\left(H^{\prime}=1,45\right)$. Hal tersebut dikarenakan nilai dominansi (D) di Poton Bakau lebih tinggi dibandingkan dengan Gili Kere, yaitu 0,46 berbanding 0,44 . Semakin tinggi nilai dominansi menunjukan adanya suatu spesies yang mendominasi komunitas tersebut sehingga komunitas tersebut labil atau tertekan (Insafitri, 2010). Hal ini juga sesuai dengan pendapat Cox (2002) yang menyatakan bahwa indeks keanekaragaman kurang dari 1 termasuk dalam kategori keanekaragaman jenisnya rendah dan tekanan ekologis sangat kuat.Spesies yang memiliki dominasi cukup tinggi di Poton Bakau adalah Enhalus acroides dengan kerapatan 41,95 tegakan $/ \mathrm{m}^{2}$ pada lokasi tersebut. Populasi yang tinggi dari satu spesies dapat menyebabkan dominansi yang pada akhirnya dapat mengakibatkan terjadinya ketidakstabilan ekosistem (Isnaningsih, 2015).

\section{Biomassa lamun}

Biomassa merupakan bahan organic hasil dari proses fotosintesis yang dilakukan oleh lamun, kemudian hasil fotosintesis disimpan pada bagian jaringan tubuh lamun (daun, rhizome, akar) (Maharani et al., 2018). Hasil perhitungan biomassa yang diperoleh dapat dilihat pada gambar 2 .

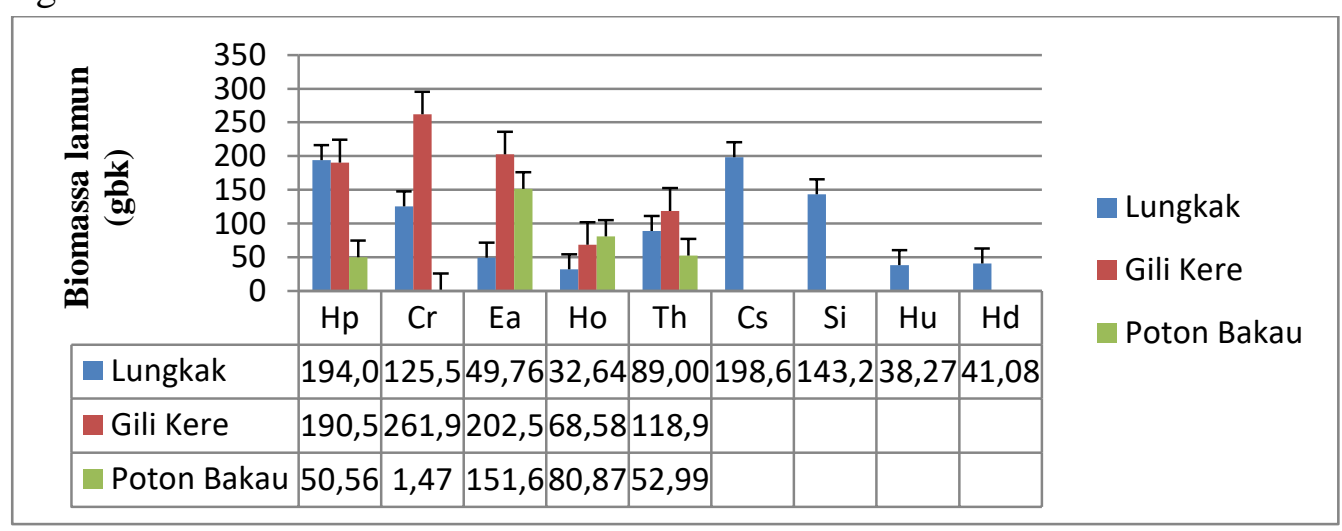

Gambar 2. Nilai biomassa setiap spesies lamun 
Total biomassa lamun yang di dapat dari ketiga lokasi yaitu 1,47-261,9 gbk/ $\mathrm{m}^{2}$. Spesies dengan nilai biomassa tertinggi di Pantai Lungkak adalah Cymodocea serullata dengan nilai $198,6 \mathrm{gbk} / \mathrm{m}^{2}$, di Gili Kere spesies dengan nilai biomassa tertinggi adalah Cymodocea rotunda dengan nilai $261,9 \mathrm{gbk} / \mathrm{m}^{2}$, dan spesies dengan nilai tertinggi di Poton Bakau adalah Enhalus acroides dengan nilai $151,6 \mathrm{gbk} / \mathrm{m}^{2}$. Tingginya nilai biomassa setiap spesies di setiap lokasi tersebut disebabkan oleh spesies tersebut memiliki morfologi daun yang besar diantara spesies lamun lainnya. Hal ini juga sesuai dengan pendapat Laffoly dan Grimsditch (2009) yang menyatakan bahwa jenis lamun yang seacara morfologi berukuran besar seperti Enhalus acroides, Thalasia hemprici, Cymodocea rotundata, dan Cymodocea serullata cenderung mengembangkan biomassa yang tinggi. Selain itu nilai kerapatan yang tinggi dan persentase tutupan juga dapat mempengaruhi nilai biomassa yang tinggi pada spesies lamun, walaupun morfologi lamun tersebut lebih kecil dibandingkan Enhalus acroides. Hal ini sesuai dengan penelitian yang dilakukan dimana nilai biomassa spesies lamun yang memiliki morfologi kecil seperti Halodule pinifoloia dan Halopila ovalis memiliki nilai biomassa yang cukup tinggi disetiap lokasi penelitian (Gambar 2). Al-Bader et al (2014) menyatakan bahwa semakin banyak rimpang dan akar yang dapat menembus sidemen maka akan dapat menciptakan ruang pori pada substart yang kemudian akan membantu dalam penyerapan nutrient dan pemasukan nutrisi pada rimpang juga substrat.

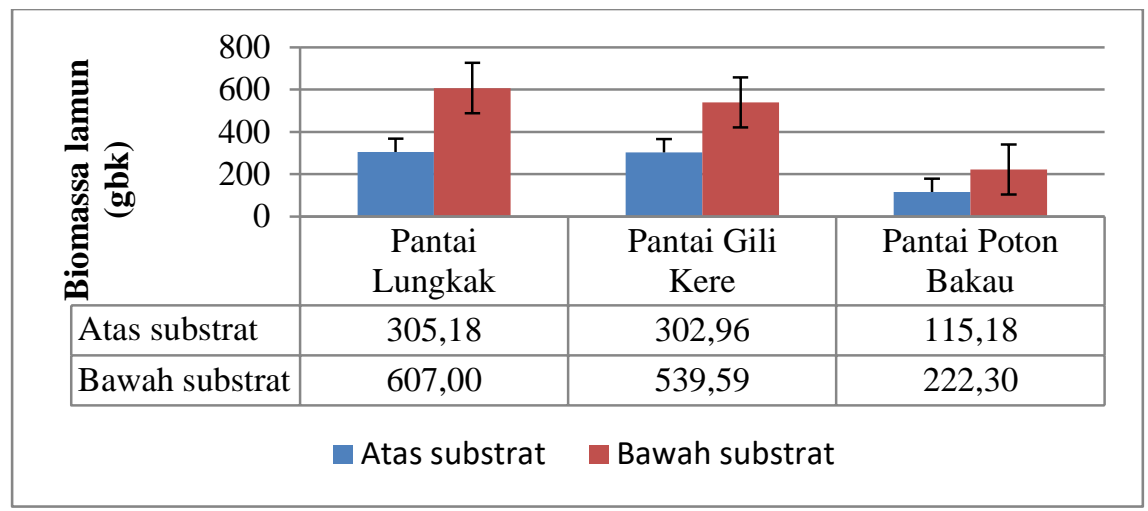

Gambar 3. Biomassa atas dan bawah substrat

Nilai biomassa di bawah substrat lebih besar daripada di atas substrat di ketiga lokasi penelitian. Nilai biomassa di bawah substrat berkisar antara 222,20-607,00 gbk/m $\mathrm{m}^{2}$ (gambar 3) lebih besar dibandingkan dengan biomassa di atas substrat $115,18-305,28 \mathrm{gbk} / \mathrm{m}^{2}$ (gambar 3), hal ini dikarenakan biomassa di bawah substrat terdiri atas akar dan rhizome sedangkan bagian atas substrat hanya terdiri dari helaian daun lamun. Bagian bawah substart yaitu rhizome banyak mengandung zat pati dan unsur hara dimana zat tersebut didistribusikan dari hasil fotosintesis yang disimpan pada bagian bawah substrat, sehingga biomassa pada rhizome di bawah substrat lebih tinggi dibandingkan jaringan lainnya (Erftemeijer,1993).

\section{Karbon lamun}

Total karbon lamun yang di dapat selama penelitian di tiga lokasi berbeda berkisar antara 295,91 $\pm 202,88$ gC. Nilai karbon tertinggi terdapat di Gili Kere dengan nilai 
439,86 $\pm 254,34 \mathrm{gC}$ dan terendah di Pantai Poton Bakau dengan nilai 175,62 $\pm 167,26 \mathrm{gC}$. Tinggi rendahnya nilai kandungan karbon juga dipengaruhi oleh luas area lamun dan nilai biomassa pada setiap jenis lamun. Nilai kandungan karbon setiap spesies lamun di lokasi peneiltian dapat dilihat pada gambar 4.

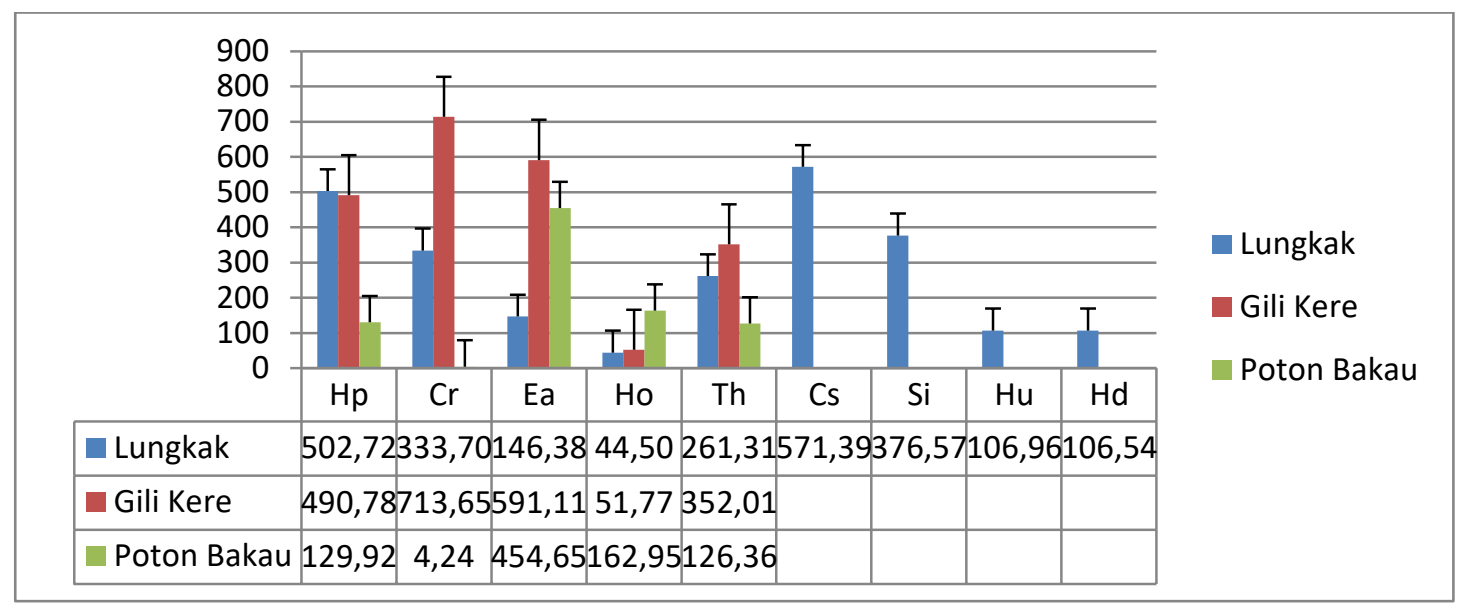

Gambar 4. Kandungan karbon spesies lamun

Nilai kandungan karbon pada spesies Cymodocea serullata di Pantai Lungkak mencapai $571,39 \mathrm{gC} / \mathrm{m}^{2}$ dan merupakan spesies lamun yang memiliki nilai kandungan yang tinggi di lokasi tersebut, sedangkan di Gili Kere spesies dengan nilai kandungan karbon tertinggi adalah Cymodocea rotundata dengan nilai $713 \mathrm{gC} / \mathrm{m}^{2}$. Selanjutnya di Pantai Poton Bakau Enhalus acroides merupakan spesies dengan nilai karbon yang paling tinggi yaitu mencapai $454,65 \mathrm{gC} / \mathrm{m}^{2}$. Setiap jenis lamun memiliki kemampuan yang berbeda dalam menyerap karbon. Sama seperti pada kemampuannya menghasilkan biomassa, lamun yang memiliki morfologi besar cenderung memiliki kandungan karbon yang lebih tinggi di banding jenis yang lebih keci (Khaerunisa et al., 2018). Menurut Pendleton et al (2012) lamun yang memiliki ukuran yang besar memiliki kemampuan yang lebih baik untuk menyimpan karbon pad lapisan sedimen yang lebih dalam dibanding lamun yang berukuran kecil sehingga pada padang lamun yang mayoritasnya ditumbuhi oleh spesies berukuran besar cenderung memiliki sedimen dengan kandungan organic tinggi. Hal tersebut berbeda dengan lamun berukuran kecil yang memiliki proses pergantian yang lebih cepat sehingga tidak dapat menyerap karbon dalam jumlah besar dan menyimpannya dalamm waktu lama. Tinggi rendahnya kandungan karbon juga dipengaruhi oleh perbedaan biomassa antar jenis lamun (Graha, 2016). Hal ini juga sesuai dengan pendapat Ganefiani (2019) yang menyatakan bahwa semakin tinggi kandungan biomassa pada lamun maka nilai kandungan karbon pada jaringan lamun juga akan semakin meningkat, yang artinya kandungan karbon berbanding lurus dengan kandungan biomassa pada lamun. Jumlah kandungan karbon dari ekosistem lamun menunjukkan nilai banyak $\mathrm{Co}_{2}$ yang diserap oleh ekositem tersebut. Semakin besar nilai kandungan karbon dari suatu ekosistem maka semakin baik, karena memberikan kontribusi besar dalam proses mitigasi perubahan iklim. 


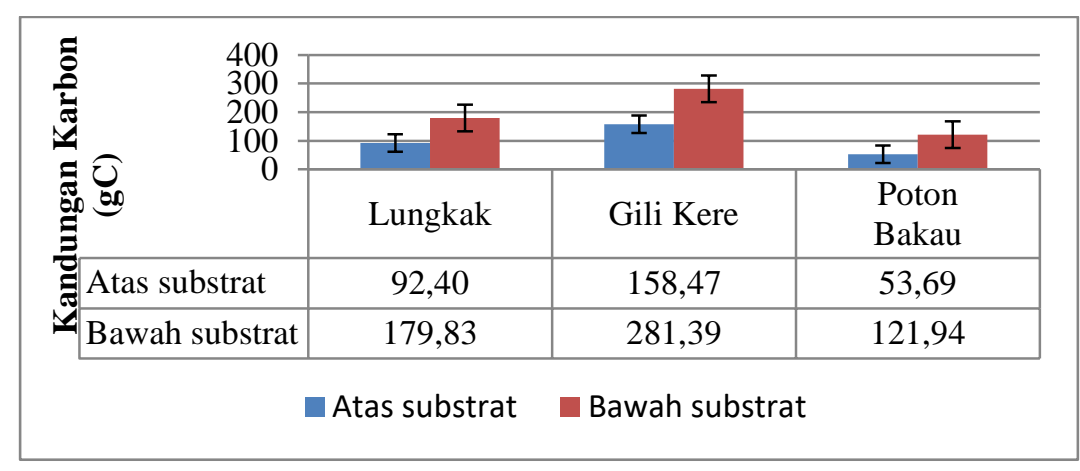

Gambar 5. Kandungan karbon bawah dan atas substrat

Hasil analisi data menunjukkan bahwa kandungan karbon yang didapat di bawah substrat berkisar antara 194,39 $\pm 135,56 \mathrm{gC} / \mathrm{m}^{2}$ lebih besar dibandingkan kandungan karbon di atas substrat yang berkisar antara 101,52 $\pm 69,97 \mathrm{gC} / \mathrm{m}^{2}$ (gambar 5), hal ini dikarenakan kandungan karbon dibawah substrat tidak terlalu tekena pengaruh factor fisik lingkungan dibandingkan dengan kandungan karbon di atas substrat yang lebih dipengaruhi oleh factor fisik perairan seperti suhu, kedalaman dan lainnya (Supriadi, 2012). Selanjutnya kandungan karbon dibawah substrat lebih tinggi dibandingkan kandungan karbon diatas substrat dikarenakan terdiri dari rhizome dan akar sedangkan bagian bawah substrat hanya terdiri dari helaian daun lamun (Rustam, et al, 2019). Kenedy et al, (2009) menyatakan bahwa kandungan karbon dibawah substrat akan tersimpan disedimen walaupun tunas pada lamun tersebut telah mati, sedangkan karbon diatas substrat hanya akan tersimpan jika tunas lamun masih hidup. Potensi penyerapan karbon akan berbanding lurus dengan luas area lamun, dimana semakin luas area lamun di perairan maka potensi penyerapan karbon akan semakin tinggi (Setiawan et al., 2012).

\section{Hubungan indeks biologi (tutupan lamun) dengan kandungan karbon}

Hubungan antara tutupan lamun dengan potensi penyimpanan karbon di Pesisir Selatan Lombok Timur di analisis menggunakan analisis korelasi pearson yang dapat dilihat pada gambar 6 .

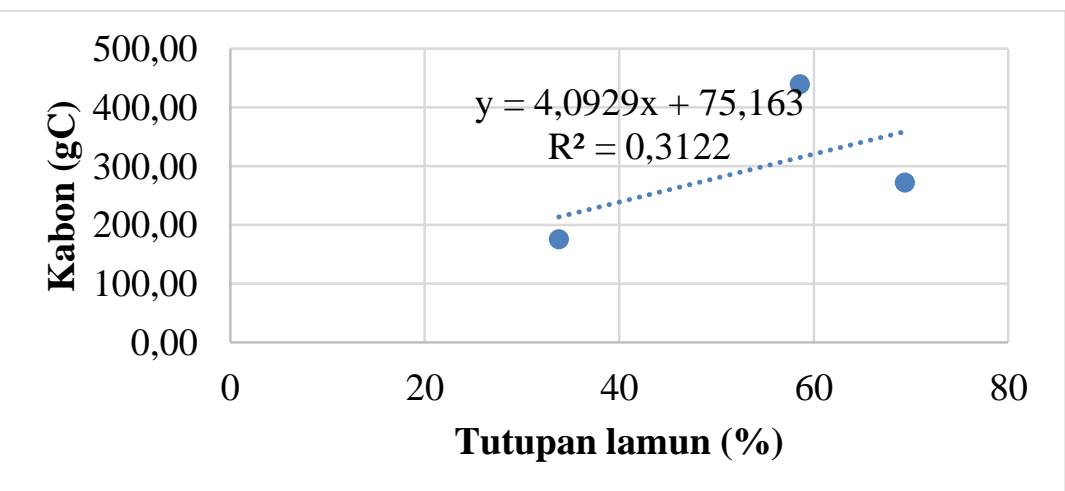

Gambar 6. Grafik hubungan tutupan lamun dengan karbon lamun

Berdasarkan gambar 6 dapat diketahui hubungan antara tutupan lamun (variabel $\mathrm{x}$ ) dengan karbon lamun (variabel y) yang menunjukkan bahwa hubungan antara tutupan lamun 
(variabel $\mathrm{x}$ ) dengan karbon lamun (variabel y) memiliki hubungan yang tergolong tinggi dengan nilai $\mathrm{r}$ 0,55. Nilai koefisien determinasi $\left(\mathrm{r}^{2}\right)$ menunjukkan bahawa tutupan lamun (variabel x) memiliki pengaruh sebesar $31 \%$ kepada variabel y (karbon) yang dimana nilai $\mathrm{r}^{2}$ adalah 0,312. Analisis regresi linier menunjukkan persamaan $y=4.0929 x+75.163$, yang memiliki arti kenaikan 1 variabel x (tutupan lamun) akan meningkatkan 4,092 variabel y (karbon lamun). Hasil analisis f-test menunjukkan bahwa terdapat hubungan yang signifikan antara variabel x (tutupan lamun) dengan variabel y (karbon lamun). Hasil yang sama disampaikan oleh Amin dan Heriyanto yang menyatakan bahwa biomassa lamun yang tinggi dikaitkan dengan kerapatan dan tutupan lamun yang tinggi. Hasil yang sama disampaikan oleh Congdon et al (2017) di dalam penelitiannya bahwa terdapat hubungan yang signifikan antara persen tutupan lamun dengan karon lamun dengan nilai $r^{2} 0,55-0,77$. Selain itu, Mashoreng et al (2018) menyatakan bahwa terdapat hubungan yang signifikan antara persen tutupan lamun dengan karbon lamun dan memiliki nilai $\mathrm{r}^{2}$ yang lebih tinggi, yaitu untuk bagian bawah substrat berkisar 0,6214-0,8866, sedangkan bagian atas substrat berkisar $0,7706-0,8968$.

\section{KESIMPULAN DAN SARAN}

Berdasarkan penelitian yang dilakukan dapat disimpulkan terdapat 9 spesies lamun di Pantai Lungkak dan 5 spesies lamun di Gili kere dan Pantai Poton Bakau. Kerapatan spesies di tiga lokasi penelitian berkidsar anatara 0,09-56,91 tegakan $/ \mathrm{m}^{2}$ Rata-rata persentase tutupan lamun dari ketiga lokasi adalah 33.8-69,4\%. Indek keanekaragaman di Pesisir Selatan Lombok Timur berkisar antara 0,99-1,92 dan termasuk dalam katagori sedang dengan tingkat kemerataan yang cukup merata. Nilai kandungan biomassa lamun yang di dapat dari ketiga lokasi yaitu 1,47-261,9 $\mathrm{gbk} / \mathrm{m}^{2}$, dan nilai biomassa dibawah substrat lebih besar dibandingkan dengan biomassa diatas substrat. Total karbon lamun yang di dapat selama penelitian di tiga lokasi berbeda adalah 295,91 $\pm 202,88 \mathrm{gC}$. Estimasi nilai kandungan karbon dibawah substrat lebih besar dibandingkan dengan estimasi nilai kandungan karbon diatas substrat. Hubungan antara tutupan lamun dengan karbon lamun memiliki hubungan yang signifikan dimana semakin tinggi tutupan lamun maka nilai kandungan karbon lamun juga akan semakin meningkat.

\section{Ucapan Terima Kasih}

Tim penelitian menyampaikan ucapan terima kasih kepada Dekan FKIP Universitas Mataram yang telah memberikan fasilitas laboratorium untuk pelaksaan penelitian.

\section{DAFTAR PUSTAKA}

Al-Bader, D.A., Shuail, D.A., Al-Hasan, R. dan Suleman, P. (2014). Intertidal Seagrass Halodule uninervis : Factor Controling its Density, Biomass and Shoot Length. Kuwait Journal Science. (41): 171-192. 
Amin, B. and T. Heriyanto. (2016). Analysis of Biomass and Carbon Reserves in Seagrass Ecosystem of Malang Rapat Villlage Bintan District, Kepulauan Riau Province, Malaysia Ecology Seminar, pp. 114-117.

Argadi, G. (2003). Struktur Komunitas Lamun di Perairan Pegerungan, Jawa Timur. Fakultas Ilmu Perikanan dan Kelautan IPB. Skripsi. Bogor.

Belshe, E. F., Hoeijmakers, D., Herran, N., Mtolera, M., \& Teichberg, M. (2018). Seagrass community-level controls over organic carbon storage are constrained by geophysical attributes within meadows of Zanzibar, Tanzania. Biogeosciences, 15(14), 4609-4626.

Brouns, J.J.W.M., Heijs, H.M.L. 1986. Production and Biomass of the Seagrases in Queenslan water. Australia: Current State of Knowledge. CRC Reef Reasearch Centre.

Brower, J.E., J.H. Zar \& Von Ende. (1990). Field and Laboratory Methods for General Ecology.Wm.C. Brown Publisher. USA. 345 pp.

Chanan, M. (2014). Pendugaan Cadangan Karbon (C) Tersimpan Di Atas Permukaan Tanah Pada Vegetasi Hutan Tanaman Jati (Tectona grandis Linn. f)(Di RPH Sengguruh BKPH Sengguruh KPH Malang Perum Perhutani II Jawa Timur). Jurnal Gamma, 7(2), 61-73.

Cox, C.B., And P.D. Moore. (2002). Biogeography: An Ecologigal and Evolutionary Approch. Blackwell Science Ltd. Oxford. 2: 98.

Duarte, C. M. (1990). Seagrass nutrient content. Marine ecology progress series. Oldendorf, 6(2), 201-207.

Erftemeijer, P.L.A., Osinga, R. and Mars, A.E. (1993). Primary Productions of Seagrass Beds in South Sulawesi (Indonesia): a Comparison of Habits, Method and Species. Aqua Bot., 46: 67-90.

Fachrul,M. F., (2007). Metode Sampling Bioekologi. PT Bumi Aksara: Jakarta 208 Hal.

Ganefiani, A., Suryanti, S., dan Latifah, N.(2019).Potensi Padang Lamun sebagai Penyerap Karbon di Perairan Pulau Karimunjawa, Taman Nasional Karimunjawa, Journal of Fisheries Science and Technology, 14(2): 115-122,

Graha, Y. I., Arthana, I. W., \& Karang, I. W. G. A. (2016). Simpanan Karbon Padang Lamun di Kawasan Pantai Sanur, Kota Denpasar. Ecotrophic: Journal of Environmental Science. 10(1), 46-53.

Handayani, E.A. (2006). Keanekaragaman Jenis Gastropoda di Pantai Randusanga Kabupaten Brebes Jawa Tengah. Skripsi. Program Studi Pendidikan Biologi Fakultas Matematika dan Ilmu Pengetahuan Alam Universitas Semarang. Semarang.

Helrich, K. (1990). Method of Analysis of The Association of Official Analytical Chemists.5th ed. Virginia.

Hidayat, Wahyu., I. W. Sukra Warpala., Ni P. Sri. Ratna Dewi. (2018). Komposisi Jenis Lamun (Seagrass) dan Karakteristik Biofisik Perairan di Kawasan Pelabuhan Desa Celukanbawang Kecamatan Gerokgak Kabupaten Buleleng Bangli. Jurnal Pendidikan Biologi Undiksha, 5 (3). ISSN 22599-1450.

Howard, J., Hoyt, S., Isensee, K., Telszewski, M., and Pidgeon, E. (eds.). (2014). Coastal Blue Carbon: Methods for Assessing Carbon Stocks and Emissions Factors in 
Mangroves, Tidal Salt Marshes, and Seagrasses. Conservation International, Intergovernmental Oceanographic Commission of UNESCO. International Union for Conservation of Nature. Arlington, Virginia, USA.

Huang, Y. H., Lee, C. L., Chung, C. Y., Hsiao, S. C., \& Lin, H. J. (2015). Carbon budgets of multispecies seagrass beds at Dongsha Island in the South China Sea. Marine Environmental Research, 106, 92-102.

Hutomo, M., \& Nontji, A. (2014). Panduan Monitoring Padang Lamun. COREMAPCTI Lembaaga Ilmu pengetahuan Indonesia, 37.

Insafitri. (2010). keanekaragaman, Keseragaman, dan Dominansi Bivalvia di Area Buangan Lumpur Lapindo Muara Sungai Porong. Jurnal Kelautan, 3(1), 54-59.

Isnaningsih, N. R., \& Patria, M. P. (2018). Peran Komunitas Moluska dalam Mendukung Fungsi Kawasan Mangrove di Tanjung Lesung, Pandeglang, Banten. Jurnal Biotropika , 6 (2), 35-44.

Kasim, M. (2013). Struktur Komunitas Padang Lamun pada Kedalaman yang Berbeda di Perairan Desa Berakit Kabupaten Bintan. Jurnal Programe Study of Marine Science : Maritim Raja Ali Haji University.

Katukdoan, M. W., Monika, N. S., \& Sunarni. (2018). Asosiasi Moluska (Gastropoda dan Bivalvia) Pada Ekosistem Magrove di Muara Sungai Kumbe. Agricola Journal, 8(1), 07-23.

Kennedy, H. \& M. Björk. (2009). Seagrass Meadows, In: Laffoley, D. D’a. \& Grimsditch, G., (Eds), (2009), The Management Of Natural Coastal Carbon Sinks, Iucn, Gland.

Khairunisa., Isdrajad Setyobudiandi., Mennofatria Boer. (2018). Estimasi Cadangan Karbon pada Lamun di Pesisir Timur Kabupaten Bintan. Jurnal Ilmu dan Teknilogi Kelautan Trpois, 10(3), 639-650.

Khouw, A. S. (2009). Metode dan analisa Kuantitatif dalam Bioekologi Laut. Penerbit: P4L dan Direktorat Jendral KP3K, Dep. Kelautan dan Perikanan RI, Ambon.

Laffoley, D. and Grimsditch, G. (2009). The Management of Natural Coastal Carbon Sinks. IUCN, Gland Switzerland.

Lisdawati; Siti Wirdhana Ahmad; La Ode Siwi. (2018). Studi Biomassaa Lamun (Enhalus acroides) dan (Halodule pinifolia) berdasarkan Kedalaman Air Laut di Pantai Desa Tanjung Tiram Sulawesi Tenggara. Jurnal Biowallacea, 5 (2): 861-870.

Lyimo, L. D. (2016). Carbon sequestration processes in tropical seagrass beds Doctoral dissertation, Department of Ecology, Environment and Plant Sciences: Stockholm University.

Magurran AE. (1988). Ecologycal Diversity and Its Measurenment. Princeton, NJ: Princeton University Press.

Maharani, Shinta., Zulkifli., Bintal Amin. (2018). Potensi Penyimpanan Karbon Lamun Thalasia hemprichi di Perairan Pantai Nirwana Kota Padang Sumatera Barat. Skripsi. Fakultas Perikanan dan Kelautan Universitas Riau: Riau.

Marbà, N., Arias-Ortiz, A., Masqué, P., Kendrick, G. A., Mazarrasa, I., Bastyan, G. R., ...\& Duarte, C. M. (2015). Impact of seagrass loss and subsequent revegetation on carbon sequestration and stocks. Journal of ecology, 103(2), 296-302. 
Marjan, M., Wardah, W., \& Hapid, A. (2016). Biomassa Dan Karbon Pohon Di Sekitar Danau Tambing Pada Kawasan Taman Nasional Lore Lindu Desa Sedoa Kecamatan Lore Utara Kabupaten Poso. Jurnal Warta Rimba. 4(1): 82-88.

Mashoreng, S., Muhamad Banda Selamat., Khairul Amri., \& Yayu Anugrah La Nafie. (2018). Hubungan Antara Persen Penutupan dan Simpanan Karbon Lamun. Jurnal Akuatika Indonesia, 3(1). ISSN: 2528-052X.

McKenzie, L., Campbell, S. J., dan Roder, C. A. (2003). Seagrass-Watch: Manual for Mapping and Monitring Seagrass Resources by Community (Citizen) Volunteers, Edisi 2. Marine Plant Ecology Group: Queensland.

Nienhius, P.H.J. Coosen and W. Kiswara. (1989). Community structure and biomass distribution of seagras and macrofauna in the Flores sea, Indonesia.Net. J. Sci. Res. 23 (2): 192-214.

Pendleton, L., D.C Donato., B.C. Murray, S. Crooks., J.W. Foourquerean., J.B. Kauffman., N. Marba., D. Gordon, and A. Baldera. (2012). Estimating global "blue carbon" emissions from conversion and degredation of vegetated coastal ecosystem. Jurnal Plus One, 7(9): 1-7. http://dx.doi.org/10.1371/journal.pone.0043542.

Putri, AE. (2004). Struktur Komunitas Lamun di Perairan Pantai Pulau Tidung Besar Kepulauan Seribu Jakarta. Fakultas Perikanan dan Ilmu Kelautan. IPB. Skripsi. Bogor.

Rahmah, F., Basri, H., \& Sufardi, S. (2015). Potensi Karbon Tersimpan Pada Lahan Mangrove dan Tambak di Kawasan Pesisir Kota Banda Aceh. Jurnal Manajemen Sumberdaya Lahan. 4(1), 527-534.

Rahman, F. A., Qayim, I., \& Wardiatno, Y. (2018). Carbon storage variability in seagrass meadows of Marine Poton Bako, East Lombok, West Nusa Tenggara, Indonesia. Biodiversitas Journal of Biological Diversity, 19(5), 1626-1631.

Rahman, A. A., Nur, A. I., \& Ramli, M. (2016). Studi Laju Pertumbuhan Lamun (Enhalus acoroides) di Perairan Pantai Desa Tanjung Tiram Kabupaten Konawe Selatan.Jurnal Sapa Laut (Jurnal Ilmu Kelautan), 1(1), 10-16.

Rahman, R., Effendi, H., \& Rusmana, I. (2017). Estimasi Stok dan Serapan Karbon pada Mangrove di Sungai Tallo, Makassar. Jurnal Ilmu Kehutanan, 11(1), 19-28.

Ramdhoni, Ahmad Zuhri. (2017). Distribusi Lamun Di Pulau Lombok, Nusa Tenggara Barat Sebagai Bahan Praktikum Mata Kuliah Ekologi Pesisir Laut. Skripsi. Fakultas Keguruan Ilmu Pendidikan. Mataram: Universitas Mataram.

Riniatsih, 1., \& Widianingsih. (2007). Kelimpahan dan Pola Sebaran Kerang-kerangan (Bivalvia) di Ekositem Padang Lamun Perairan Jepara. Jurnal Ilmu Kelautan, 12 (1).

Rustam, A. (2019). Pengukuran Karbon di Ekosistem Padang Lamun, Edisi 1, ITB Press, Bandung.

Setiawan, F., Harahap, S.A., Andriani, Y. \% Hutahaean, A.A. (2012). Deteksi Perubahan Padang Lamun menggunakan Teknologi Pengindraan Jauh dan Kaitannya dengan Kemampuan Menyimpan Karbon di Periaran Teluk Banten. Jurnal Perikanan dan Kelautan, 3(3): 275-286. 
Short, F. T., dan Coles, R. G.(2001). Global Seagrass Research Methods, Edisi 1, Elsevier: Amsterdam.

Supriadi, Richardus F., Kaswadji, Dietrich G., Bengen, dan Malikusworo H. (2012). Stock dan Neraca Karbon Komunitas Lamun di Pulau Baranglompo, Makassar. Jurnal Ilmu Kelautan. (1): 1-10.

Supriadi, S., Kaswadji, R. F., Bengen, D. G., \& Hutomo, M. (2014). Carbon Stock of Seagrass Community in Barranglompo Island, Makassar (Stok Karbon pada Komunitas Lamun di Pulau Barranglompo, Makassar). Ilmu Kelautan: Indonesian Journal of Marine Sciences, 19(1), 1-10.

Tangke, U. (2010). Ekosistem Padang Lamun (Manfaat, Fungsi Dan Rehabilitasi). Agrikan: Jurnal Agribisnis Perikanan, 3(1), 9-29.

Tomascick, T., A.J. Mah, A. Nontji \& M.K. Kasim Moosa. (1997). The Ecology of the Indonesia Seas. Part One. Periplus Edition (HK) Ltd., Singapore.

Wawo, M., Wardiatno, Y., Adrianto, L., \& Bengen, D. G. (2014). Carbon stored on seagrass community in marine nature tourism park of Kotania Bay, Western Seram, Indonesia. Jurnal Manajemen Hutan Tropika, 20(1), 51-57.

Windarni, C., Setiawan, A., \& Rusita, R. (2017). Estimasi Karbon Tersimpan pada Hutan Mangrove di Desa Margasari Kecamatan Labuhan Maringgai Kabupaten Lampung Timur. Jurnal Sylva Lestari, 6(1), 66-74.

Yunita, R. R., Suryanti, S., dan Latifah, N. (2020). Biodiversitas Echinodermata pada Ekosistem Lamun di Perairan Pulau Karimunjawa. Jurnal Kelautan Tropis, 23(1): 47-56, https://doi.org/https://doi.org/10.14710/jkt.v23i1.3384 